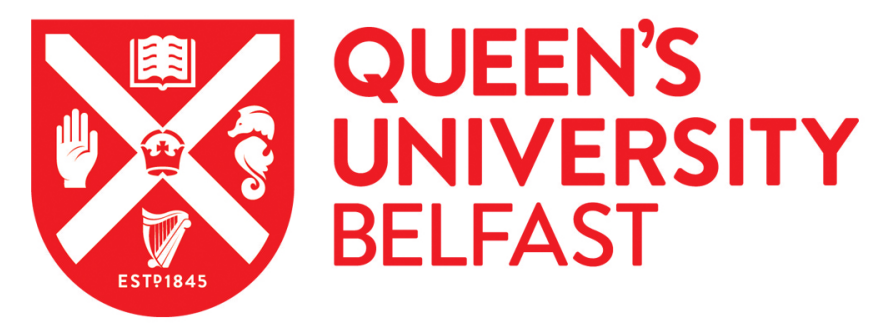

\title{
Mangrove density impacts on surface sediment accretion, belowground biomass and biogeochemistry in Puttalam Lagoon, Sri Lanka
}

Phillips, D. H., Kumara, M. P., Jayatissa, L. P., Krauss, K. W., \& Huxham, M. (2017). Mangrove density impacts on surface sediment accretion, belowground biomass and biogeochemistry in Puttalam Lagoon, Sri Lanka. Wetlands, 37(3), 471-483. https://doi.org/10.1007/s13157-017-0883-7

Published in:

Wetlands

Document Version:

Peer reviewed version

Queen's University Belfast - Research Portal:

Link to publication record in Queen's University Belfast Research Portal

Publisher rights

Copyright 2017 US Government

The final publication is available at Springer via http://link.springer.com/article/10.1007\%2Fs13157-017-0883-7

\section{General rights}

Copyright for the publications made accessible via the Queen's University Belfast Research Portal is retained by the author(s) and / or other copyright owners and it is a condition of accessing these publications that users recognise and abide by the legal requirements associated with these rights.

Take down policy

The Research Portal is Queen's institutional repository that provides access to Queen's research output. Every effort has been made to ensure that content in the Research Portal does not infringe any person's rights, or applicable UK laws. If you discover content in the Research Portal that you believe breaches copyright or violates any law, please contact openaccess@qub.ac.uk. 
6

27

\title{
Impacts of Mangrove Density on Surface Sediment Accretion,
} Belowground Biomass and Biogeochemistry in Puttalam Lagoon, Sri Lanka

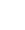

4

5

(1)

(1)

\author{
D.H. Phillips ${ }^{1 *}$, M.P. Kumara ${ }^{2}$, L.P. Jayatissa ${ }^{3}$, K.W. Krauss ${ }^{4}$, M. Huxham ${ }^{5}$
}

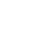

(1)

(1)

1

2

3

4

5

6

7

${ }^{1}$ School of Natural and Built Environment, Queen's University of Belfast, Belfast, Northern Ireland, UK *Corresponding author: d.phillips@qub.ac.uk, phone number +44 (0)28 9097-5590.

${ }^{2}$ Faculty of Fisheries and Marine Science, Ocean University of Sri Lanka, Mahawela road, Tangalle, Sri Lanka

${ }^{3}$ Dept. Botany, University of Ruhuna, Matara, Sri Lanka

${ }^{4}$ U.S. Geological Survey, Wetland and Aquatic Research Center, 700 Cajundome Blvd., Lafayette, LA 70506, USA

${ }^{5}$ School of Applied Sciences, Edinburgh Napier University, Edinburgh, Scotland, UK 


\section{Abstract}

Understanding the effects of seedling density on sediment accretion, biogeochemistry and belowground biomass in mangrove systems can help explain ecological functioning and inform appropriate planting densities during restoration or climate change mitigation programs. The objectives of this study were to examine: 1) impacts of mangrove seedling density on surface sediment accretion, texture, belowground biomass and biogeochemistry, and 2) origins of the carbon (C) supplied to the mangroves in Palakuda, Puttalam Lagoon, Sri Lanka. Rhizophora mucronata propagules were planted at densities of 6.96, 3.26, 1.93 and 0.95 seedlings $\mathrm{m}^{-2}$ along with an unplanted control ( 0 seedlings $\left.\mathrm{m}^{-2}\right)$. The highest seedling density generally had higher sediment accretion rates, finer sediments, higher belowground biomass, greatest number of fine roots and highest concentrations of $\mathrm{C}$ and $\mathrm{N}$ (and the lowest $\mathrm{C} / \mathrm{N}$ ratio). Sediment accretion rates, belowground biomass (over 1370 days), and C and N concentrations differed significantly between seedling densities. Fine roots were significantly greater compared to medium and coarse roots across all plantation densities. Sulphur and carbon stable isotopes did not vary significantly between different density treatments. Isotope signatures suggest surface sediment $\mathrm{C}$ (to a depth of $1 \mathrm{~cm}$ ) is not derived predominantly from the trees, but from seagrass adjacent to the site.

Keywords Mangroves, Sediment nutrients, Accretion, Facilitation, Sri Lanka, Biogeochemistry, Belowground biomass, Stable isotopes, Carbon

\section{Introduction}

Mangrove forests trap sediment within their complex aboveground root structures and can influence soil surface elevation; healthy forests with adequate sediment supplies can, therefore, contribute to vertical land building (Wolanski et al., 1992; Furukawa et al., 1997; Krauss et al., 2003; Huxham et al., 2010; Kumara et al., 2010). The distribution of different sediment types 
1 within mangroves and coastal wetlands depends on local sources of sediment, hydrological

2 conditions, wind and resistance to water flow imposed by the plants (Yang et al., 2008;

3 Ramanathan et al., 2009). The texture and mineralogy of the sediments are closely coupled with

4 local biogeochemical and ecological processes and affect the local nutrient and chemical cycles

5 (Jahnke, 2005; Prasad and Ramanathan, 2009). Hence, mangrove trees influence the nature and

6 amount of sediment present, which in turn may influence the growth of the trees.

$7 \quad$ Mangrove belowground biomass studies can help in understanding nutrient turnover and

8 the potential to store C; however, information on belowground stock is scant (Tamooh et al.,

9 2008). Belowground standing stock generally ranges between 0.72 to $30.62 \mathrm{~kg} \mathrm{~m}^{-2}$ worldwide

10 (Komiyama et al., 2008; Tamooh et al., 2008) although Cormier et al. (2015) report belowground

11 biomass as low as 0.45 to $2.64 \mathrm{~kg} \mathrm{~m}^{-2}$ for mangroves in Micronesia. Variations in species

12 diversity, tree density, forest age, level of disturbances and tree growth rates all contribute to this

13 large variance among different mangrove forests. Understanding belowground productivity under

14 different mangrove densities provides the opportunity to broadly illustrate total mangrove

15 productivity (Saintilan, 1997a,b; Komiyama et al., 2000; Alongi and Dixon, 2000; Ong et al.,

16 2004; Comley and McGuinness, 2005; Tamooh et al., 2008). Studying processes involving root

17 dynamics is important in understanding forest functions, particularly in mangroves that may invest

18 proportionately large amounts of productivity into their root systems (Saintilan, 1997a,b; McKee

19 et al., 2007). Additionally, fine roots are the principal pathway for nutrient absorption for plants,

20 therefore understanding their distribution in the soil can increase understanding of soil nutrient

21 distribution.

In mangrove forests, most of the nutrient pool is stored in the sediment and not in the trees

23 (Alongi, 2009). Despite typically low levels of macronutrients, mangroves manage to sustain 
1 very high rates of primary productivity; an average productivity of $0.0025 \mathrm{~kg} \mathrm{C} \mathrm{m}^{-2} \mathrm{~d}^{-1}$ makes

2 them important components of coastal biogeochemical cycles (Bouillon et al., 2002). This is

3 probably achieved by efficient nutrient cycling and conservation, along with the ability to capture

4 nutrients from outside the system (Alongi, 2009). Allochthonous and autochthonous material is

5 physically, chemically and biologically decomposed in mangrove substrates, with the subsequent

6 organic materials through microbial enrichment processes (Odum and Heald, 1975). Despite this,

7 most mangrove forests experience nutrient limitation, sometimes by phosphorus (Lovelock et al.,

8 2007), more often by nitrogen (Alongi, 2009, p38; Reef et al., 2010), and with complex

9 interactions between the two depending in part on location. Studying the physical processes of

10 sediment capture is one important way of understanding controls on growth in mangrove forests,

11 since sediment volume and type may link with nutrient availability, and sediment supply may

12 itself stimulate or repress growth (Lovelock et al., 2007).

Sedimentary processes also help to determine the influence of mangroves on coastal

14 geomorphology and erosion. Surface accretion is the height increment of the sediment layer due

15 to gradual deposition of sediment particles and organic material. Surface elevation is the upward

16 movement of sediment due to surface accretion combined with subsurface processes, such as

17 sediment expansion and root growth, discounting for shallow subsidence. These two processes

18 can determine whether the forest floor maintains elevation in relation to sea level, and therefore

19 whether mangroves can help adapt to or mitigate the influence of sea level rise (Gilman et al.,

20 2006; McLeod and Salm, 2006; McKee et al., 2007; Gilman et al., 2007, 2008; Krauss et al.,

21 2014). Higher plant densities should result in slower current speeds and enhanced accretion,

22 which may contribute to elevation. So exploring the impacts of tree density on surface accretion

23 can increase understanding of coastal geomorphology as well as biogeochemical dynamics. One 
1 important applied aspect of this understanding is in coastal restoration and mangrove planting,

2 which is often executed to provide erosion control. Dramatic losses in Sri Lankan mangroves,

3 particularly in the west of the country (Bournazil et al., 2015), combined with the impact of the

4 Asian tsunami, generated extensive mangrove restoration activity within the country (see e.g.

5 IUCN, 2009). Mangrove restoration often fails; Gedan and Silliman (2009) suggest that one

6 reason for this is a failure to anticipate positive plant-plant interactions during early establishment,

7 which may help to overcome establishment thresholds imposed by hydrodynamic forces (Friess et

8 al., 2012). By using a field experiment to examine sedimentary processes during the first two

9 years post-planting the current work may inform the design of mangrove restoration projects.

Measuring the ratios of the stable isotopes of carbon in organic material can provide

11 insights into the source of the material. Different taxa of plants synthesize organic carbon (OC)

12 with distinct ${ }^{13} \mathrm{C} /{ }^{12} \mathrm{C}$ values, due to differences in isotopic discrimination by their photosynthetic

13 enzymes and the regulation of diffusion resistance by their stomata (Schweizer et al., 1999; Smith

14 and Epstein, 1971). This C breaks down to detritus and mixes into soil, water or sediments. The

15 movement of sediment may transport this $\mathrm{C}$ to different locations, while its original isotopic ratio

16 remains unchanged. Hence, stable isotope ratios provide a means of tracing the origins of $\mathrm{C}$ in

17 marine sediments (Fry, 2006; Bouillon et al., 2007; Prasad and Ramanadan, 2009; Otero et al.,

18 2000; Bauer et al., 2002). C/N ratios can also be used as indicators for identifying depositional

19 coastal sediment sources (Yu et al., 2010). However, biological alterations or chemical and

20 physical processes in sediments may weaken the capacity of the $\mathrm{C} / \mathrm{N}$ ratio to distinguish the

21 original source of C (Thornton and McManus, 1994). To overcome this constraint, $\mathrm{C} / \mathrm{N}$ ratios

22 combined with bulk organic $\delta^{13} \mathrm{C}$ can provide an effective indicator for identifying coastal

23 sediment sources (Yu et al., 2010). For instance, a low C/N ratio coincident with less negative 
$1 \quad \delta^{13} \mathrm{C}$ signatures indicates sediments receiving marine or estuarine particulate suspended matter

2 (Bouillon et al., 2003). The present study combines these approaches to understand the likely

3 origin of sedimentary material in experimental mangrove plantations.

4

5

\section{Study site and experimental design} lagoon bed.

Whilst tree or root density often correlates with sedimentary characteristics (eg Krauss et al., 2003), mangrove systems are highly variable and differences observed in un-manipulated forests may be caused by large numbers of confounding factors. Hence an experimental approach can complement such work by controlling confounders. Here, we use a controlled experiment to study the effects of mangrove tree density on surface sediment texture, accretion, belowground biomass and biogeochemistry. We also examine the origins of the sediment $\mathrm{C}$ and $\mathrm{N}$ supplied to the mangroves in a study site in the Palakuda, Puttalam Lagoon on the west coast of Sri Lanka.

\section{Materials and Methods}

The study site is at Palakuda, in Puttalam Lagoon, on the west coast of Sri Lanka (Figure 1: $8.08^{\circ} \mathrm{N} ; 79.73^{\circ} \mathrm{E}$ ). Maximum tidal range in the lagoon is $60 \mathrm{~cm}$ with an average of two high tides per day. The surface area of the Puttalam Lagoon is around $400 \mathrm{~km}^{2}$ and it is generally very shallow (1-2m), except in the central areas of the lagoon where it can be as deep as $5 \mathrm{~m}$. The lagoon receives two major perennial freshwater inputs from the Kala Oya and Mee Oya Rivers (Figure 1). The salinity of the lagoon varies from oceanic levels ( 35 psu) at the northern outlet to 0 psu at river discharge points to hypersaline in the extreme southern portion of the lagoon (Johnson and Johnstone, 1995). Salinity averaged 23 psu at the field site. The experimental site is classified as a flow-through system where the exchange of water repeatedly sweeps the entire 
Rhizophora mucronata is common in Sri Lankan mangrove forests (Jayatissa et al., 2002),

2

and it occurs naturally at the site. The species grows tall (around 25m), producing considerable numbers of prop roots, and it exhibits vivipary resulting in large stick-like propagules (up to 80 cm in length, Duke, 2006) (Kathiresan and Bingham, 2001).

In May 2006, fifteen $7.2 \mathrm{~m} \times 7.2 \mathrm{~m}$ plots, arranged in three blocks of five treatments each, with a minimum gap of $1.2 \mathrm{~m}$ between plots, were demarcated in the selected mud flat, in an area close to and between patches of natural forest and at the same tidal elevation (Figure 2). The site was chosen after consulting local villagers, who supported mangrove planting here; whilst the area has suffered extensive mangrove deforestation, and there are efforts to restore degraded areas, to our knowledge there were no trees present in the past on these specific experimental plots. Plots were randomly assigned to one of five treatments within each block, which included four planting densities (6.96, 3.26, 1.93 and 0.95 . mucronata seedlings $\mathrm{m}^{-2}$ ) and an unplanted control ( 0 seedlings $\mathrm{m}^{-2}$ ); hence the highest density treatment was $\sim$ seven times more dense than the lowest and treatments spanned the range of densities found for juveniles in nearby forest. Planting densities equated to 361, 169, 100, 49 and 0 seedlings per treatment. Hence, each treatment was replicated three times within a randomized block design, with blocks included to help account for spatial variability and not to test for hypotheses. For additional details on experimental design, refer to Kumara et al. (2010).

\section{Sediment Accretion, Particle Size, Chemical Analysis}

At 880 days (approx. 2.4 years) after plantation establishment, four sediment surface scrapes $(1 \mathrm{~cm}$ depth $\times 10 \times 10 \mathrm{~cm}$ area) were taken from random points within each quarter of every plot and combined to give one sample per replicate. Samples were air-dried before being subdivided for carbon, nutrients, particle size and isotopes analyses. 
Vertical sediment accretion among different densities was measured by setting a mixture

2 of $50 \%$ powdered feldspar and $50 \%$ white sand over a $30 \times 30 \mathrm{~cm}$ surface area in the centre of each plot immediately after the trees were planted (Cahoon and Lynch, 1997). Plugs $\left(1 \mathrm{~cm}^{2} \times 5\right.$ cm deep) were cut out of the sediment in the marker horizon plots and the sediment accretion was measured as the distance from the top of the plug to the feldspar marker horizon with a 1-mm accuracy. Four sediment plugs were measured and averaged to give a single reading for each treatment at each sampling time; marker horizons were replaced every two or three months. Constant re-application of marker horizons creates slightly positive biases in accretion estimates because long-term settling of deposited sediments is not included and some erosion may be inadvertently ignored (Cahoon and Lynch, 1997). However, marker horizons in this study were lost frequently, perhaps because of the regular exchange of water that repeatedly sweeps the entire lagoon bed. Thus, they were re-applied consistently across all treatments. Consequently, overall rates of surface accretion might be slightly higher than long-term averages. Cumulative accretion values and annual accretion rates $\left(\mathrm{mm} \mathrm{yr}^{-1}\right)$ were calculated for each treatment. Small quantities ( 1g) of collected sediments were sonicated for 5 minutes using a ColePalmer Ultrasonic Homogenizer sonicator on the sediment scrape samples. The \% clay $(<0.002 \mu \mathrm{m})$, very fine silt $(0.002-0.0032 \mu \mathrm{m})$, fine silt $(0.0032-0.0063 \mu \mathrm{m})$, medium silt $(0.0063$ $0.02 \mu \mathrm{m})$, coarse silt $(0.02-0.063 \mu \mathrm{m})$, very fine sand $(0.063-125 \mu \mathrm{m})$, fine sand $(125-250 \mu \mathrm{m})$, medium sand $(0.25-0.5 \mathrm{~mm})$, coarse sand $(0.5-1 \mathrm{~mm})$ and very coarse sand $(1-2 \mathrm{~mm})$ were measured using a Malvern Mastersizer 2000 laser diffraction particle-size analyzer (LDPSA) equipped with a Hydro 2000G. 

pH was determined on a 1:1 ratio w/v of soil and deionized water (Peech, 1965) using a Jenway

$3 \quad 3150 \mathrm{pH}$ meter.

4

\section{Belowground Biomass}

A total of 48 soil cores (40-cm deep and 15-cm diameter) were taken at random points within each quarter of each planted plot, giving four sub samples per plot, at Palakuda, Puttalam 1370 days after planting. Each core was sequentially cut into 8 equal depth slices (of $5 \mathrm{~cm}$ depth each) using a sharp knife. Each slice was washed over a 1-mm mesh and the extracted roots were sorted into three classes; $<5$-mm diameter (fine roots), 5-10- mm (medium roots), and >10-mm (coarse roots). The three root types from each core were weighed to the nearest $0.01 \mathrm{~g}$ to record the wet weights of different root types per core. The roots were then dried to a constant weight at $60^{\circ} \mathrm{C}$ and were used for calculating the mean dry weight of fine, medium and coarse roots per core.

\section{Isotope Analysis}

The sediment scrape samples were oven-dried at $60^{\circ} \mathrm{C}$, and then ground to fine powder $(\leq 45 \mu \mathrm{m})$ using a Wiley mill. Subsamples for $\delta^{13} \mathrm{C}$ analysis were washed with dilute HCl to remove possible carbonates and were re-dried. Subsamples for $\delta^{15} \mathrm{~N}$ were not subjected to this treatment as the acidification affects the $\delta^{15} \mathrm{~N}$ values (Pinnegar and Polunin, 1999). Samples for $\delta^{13} \mathrm{C}$ and $\delta^{15} \mathrm{~N}$ analysis were similarly combusted in an elemental analyzer, coupled to an InfraRed Mass Spectrometry (IRMS) and SP6-350 Visible Spectrophotometer, respectively, via an open split interface. The relative abundance of the heavy and light isotopes of $\mathrm{C}$ and $\mathrm{N}$ were expressed as $\delta^{13} \mathrm{C}$ and $\delta^{15} \mathrm{~N}(\%)$ values by integrated computer analysis. Isotope ratios were calculated using the following equations. 
2

$3 \quad \delta^{13} \mathrm{C}=\left[\left(\mathrm{R}_{\text {SAMPLE }} / \mathrm{R}_{\text {STANDARD }}\right)-1\right] \times 1000$

Eq 1

$4 \quad \delta^{13} \mathrm{C}=$ difference measurement made relative to standards (Stable $\mathrm{C}$ isotope signatures)

$5 \quad \mathrm{R}=$ the ratio of the heavy isotope to the light isotope for the element $\left({ }^{13} \mathrm{C} /{ }^{12} \mathrm{C}\right)$. Equation 2 was to determine the $\mathrm{N}$ from a specific source in mixed sediments, where

$7 \quad \delta^{15} \mathrm{~N}=[(\mathrm{R}$ SAMPLE $/ \mathrm{R}$ STANDARD $)-1] \times 1000$ Eq 2

$8 \quad \delta^{15} \mathrm{~N}=$ difference measurement made relative to standards (Stable $\mathrm{N}$ isotope signature)

$9 \quad \mathrm{R}=$ the ratio of the heavy isotope to the light isotope for the element $\left({ }^{15} \mathrm{~N} /{ }^{14} \mathrm{~N}\right)$.

Statistical analysis

Data were analysed for normality and homoscedasticity among residual variances and each

12 response variable, with the exception of fine root density, was compared among different planting

13 densities using two-way ANOVA tests with treatments and blocks as factors. In order to explore

14 the effects of soil depth on fine root density, treatments and soil layers were used as factors in a

15 two-way ANOVA with the fine root density as the response. The blocking factor in this analysis

16 was first tested using aggregate data across layers, and then removed because it was non-

17 significant. Post-hoc multiple range tests were conducted with Bonferroni adjustment (Tukey’s tests). All statistical analyses were carried-out using Minitab, Version 14.20 (Minitab Inc., State

19 College, PA, USA) or SPSS, Version 13.0 (SPSS Inc., Chicago, IL, USA) statistical packages.

\section{Results}

\section{Surface Sediment Accretion and Texture in Different Mangrove Densities}


Surface sediment accretion rates differed significantly among treatments $(\mathrm{p}<0.01)$.

2 Accretion rates increased with tree density (Figure 3). The natural sediment accretion of the site

3 measured on the Control Plots (mean \pm SE of $7.4 \pm 0.3 \mathrm{~mm} \mathrm{yr}^{-1}$ ) was more than doubled to a level

4 of $16.2 \pm 1.3 \mathrm{~mm} \mathrm{yr}^{-1}$ under the highest planting density $\left(6.96 \mathrm{~m}^{-2}\right)$. The rate of accretion was

5 significantly higher in the 6.96 density treatment $(\mathrm{p}<0.05)$ compared with all the other densities,

6 whilst that in the 3.26 density treatment was significantly higher $\left(\mathrm{p}^{<0.05}\right)\left(12.7 \mathrm{~mm} \mathrm{yr}^{-2}\right)$ than the

$7 \quad 1.93\left(10.6 \mathrm{~mm} \mathrm{yr}^{-2}\right), 0.95\left(8.6 \mathrm{~mm} \mathrm{yr}^{-2}\right)$ and control densities (Figure 3).

8 The texture classification of the sediment across the study was medium sand which

9 showed a significant difference across the Palakuda planted plots. The plots recorded 79.75 to

\section{Belowground Biomass}

\section{Density of Different Root Types $\left(\mathrm{m}^{-2}\right)$}

The mean number of total roots $\left(\mathrm{m}^{-2}\right)$ and fine roots $\left(\mathrm{m}^{-2}\right)$ showed significant differences among the treatments (Figures 4a. c). Tukey's comparisons showed that the highest density treatment (6.96) contained the highest fine and total root densities $\left(\mathrm{m}^{-2}\right)$ over the lowest seedling density (0.95). The highest seedling density had $3751 \pm 426 \mathrm{~m}^{-2}$ fine roots, 2.4 times higher than that of the lowest tree density $\left(1574 \pm 359 \mathrm{~m}^{-2}\right)$. Thus, increasing the density by approximately 7.3 times increased the fine root density by 2.4 times. Regardless of the significant increase in fine roots, none of the tree densities showed significant differences for medium or coarse roots which could be due to these roots having more of a structural/support function. 
1 Fine Root Density $\left(\mathrm{m}^{-2}\right)$ at Different Soil Depths

2

3

4

5

6

7

8

9

10

11

The mean fine root density $\left(\mathrm{m}^{-2}\right)$ significantly varied among the plantation densities (Figure 4b) in the 5-10 cm layer. The mean fine root density of the 6.96 seedling $\mathrm{m}^{-2}$ plantation density (805 $\pm 121 \mathrm{~m}^{-2}$ ) within the 5-10 cm layer was significantly higher (Tukey test; $\mathrm{p}<0.05$ ) than fine root densities of the $1.93(281.6 \pm 11.6)$ and 0.95 (333.5 \pm 83.4) plantation densities, while the fine root density of the 3.26 seedling $\mathrm{m}^{-2}$ plantation density did not differ from the densest seedling plots. The 3.26, 1.93 and 0.95 seedling $\mathrm{m}^{-2}$ plantation densities were not different from each other within this 5-10cm layer. The mean fine roots density $\left(\mathrm{m}^{-2}\right)$ of different plantation densities significantly differed in the $10-15 \mathrm{~cm}$ layer where the 6.96 seedling $\mathrm{m}^{-2}$ plantation density $\left(753 \pm 90.4 \mathrm{~m}^{-2}\right)$ was significantly higher $(\mathrm{p}<0.05)$ than those of the 0.95 seedling $\mathrm{m}^{-2}$ plantation density (321.7 \pm 50.5$)$. All tree densities showed a general pattern of reduction of fine root densities with depth.

\section{Belowground Dry Biomass}

The total belowground biomass $\left(\mathrm{g} \mathrm{m}^{-2}\right)$ significantly varied among the treatments. The highest seedling density $\left(6.96 \mathrm{~m}^{-2}\right)$ contained the highest belowground dry weight $(105.41 \pm 6.98$ $\mathrm{g} \mathrm{m}^{-2}$; Figure 4c), while the other densities did not significantly differ $(\mathrm{p}>0.05)$. The total belowground biomass was $27.6 \pm 5.3 \mathrm{~g} \mathrm{~m}^{-2}$ in the $0.95 \mathrm{~m}^{-2}$ plot, $35.57 \pm 2.3 \mathrm{~g} \mathrm{~m}^{-2}$ in the $1.93 \mathrm{~m}^{-2}$ plot, and $55.5 \pm 19.6 \mathrm{~g} \mathrm{~m}^{-2}$ in the $3.26 \mathrm{~m}^{-2}$ plot.

\section{Carbon, Nitrogen, Sulphur and pH}

The percentage of total $\mathrm{C}$ in the surface sediment varied significantly among the treatments (Figure 5). For the highest density of 6.96 seedlings $\mathrm{m}^{-2}$, the $\% \mathrm{C}$ (mean $\pm \mathrm{SE}$ ) was 0.68 ( \pm 0.04$)$, while the $C$ values for $3.26,1.93,0.95$ and 0 seedlings $m^{-2}$ were $0.55( \pm 0.08), 0.53$ 
1 ( \pm 0.05$), 0.54( \pm 0.04)$, and $0.46( \pm 0.05)$, respectively. Tukey`s comparisons showed a

2 significantly higher $\mathrm{C}$ in the highest (6.96 seedlings $\mathrm{m}^{-2}$ ) seedling density, compared to the

3 unplanted controls. There were no significant differences in the sediment $\mathrm{C}$ among the other

4 treatments.

$5 \quad$ Sediment $\mathrm{N}$ also varied significantly $(\mathrm{p}<0.05)$ among plantation densities; the $\% \mathrm{~N}$ in

6 surface sediments in the $6.96 \mathrm{~m}^{-2}$ density treatment was significantly higher $(\mathrm{p}<0.05)$ compared

7 with the other treatments (which showed no significant differences among themselves; Figure 5).

8 For the highest density of 6.96 seedlings $\mathrm{m}^{-2}$, the $\% \mathrm{~N}$ (mean $\pm \mathrm{SE}$ ) was $0.08( \pm 0.007$ ), while the

$9 \mathrm{~N}$ values for $3.26,1.93,0.95$ and 0 seedlings $\mathrm{m}^{-2}$ were $0.06( \pm 0.009), 0.007( \pm 0.003), 0.07( \pm$

10 0.006), and $0.05( \pm 0.001)$, respectively.

$11 \quad \mathrm{C} / \mathrm{N}$ ratios for the sediments showed no significant differences among planted treatments

12 but differed significantly between the planted treatments and the control; the latter showed the

13 highest mean ratio which was significantly greater than 1.93 and 0.95 densities. $\mathrm{C} / \mathrm{N}$ ratios for

$14 \quad 6.96,3.26,1.93,0.95$ and 0 seedlings $m^{-2}$ were $9.01( \pm 0.52), 8.53( \pm 0.35), 7.85( \pm 0.53), 7.88( \pm$

15 0.51), and $9.32( \pm 0.72)$, respectively (Table 2$)$.

Sulphur did not vary significantly among the different density treatments (Figure 5)

17 indicating an adequate supply for the seedlings irrespective of the higher demand in the higher

18 seedling densities. For the highest density of 6.96 seedlings $\mathrm{m}^{-2}$, the $\% \mathrm{~S}$ (mean $\pm \mathrm{SE}$ ) was $0.12( \pm$

19 0.02), while the $S$ values for $3.26,1.93,0.95$ and 0 seedlings $m^{-2}$ were $0.09( \pm 0.00), 0.11( \pm 0.01)$,

$20 \quad 0.11( \pm 0.01)$, and $0.07( \pm 0.00)$, respectively. Levels of S were not significantly different

21 between the unplanted controls and the planted plots. This implies that seedling growth is

22 unlikely to be limited by macronutrients needed for normal development in plants. 

differences.

4 Stable Isotopes

$5 \quad$ The mean $\delta^{13} \mathrm{C}$ values for sediment taken from the 6.96, 3.26, 1.93, 0.95 and 0 seedlings

$6 \mathrm{~m}^{-2}$ treatments did not differ significantly (Table 2$)$. The \%o $( \pm \mathrm{SE}) \delta^{13} \mathrm{C}$ values for 6.96, 3.26,

$7 \quad$ 1.93, 0.95 and 0 seedlings $\mathrm{m}^{-2}$ were $-16.13( \pm 0.95),-15.85( \pm 0.97),-15.71( \pm 0.40),-16.41( \pm$

8 0.14), and $-14.58( \pm 0.30)$, respectively. The absence of significant differences in isotopic

9 signatures suggests that much of this soil surface $C$ was allochthonous and arrived with the 10 accreting sediment.

There were no significant differences among mangrove density in $\delta^{15} \mathrm{~N}$ values in

12 sediments (Table 2). The $\%$ ( $( \pm \mathrm{SE}) \delta^{15} \mathrm{~N}$ values for $6.96,3.26,1.93,0.95$ and 0 seedlings $\mathrm{m}^{-2}$

13 were 2.80 ( \pm 0.13$), 2.73$ ( \pm 0.29$), 2.40$ ( \pm 0.24$), 2.41$ ( \pm 0.22$)$, and $2.49( \pm 0.11)$, respectively.

14

15

16

17

18

19

20

21

22

\section{Discussion}

\section{Higher Mangrove Densities Increase Sediment Accretion}

The increased drag coefficient at higher mangrove densities slows water movement and facilitates sediment accretion (Quartel et al., 2007; Furukawa and Wolanski, 1996). Ambient sediment accretion measured on the control plots (mean \pm SE of $7.4 \pm 0.3 \mathrm{~mm} \mathrm{yr}^{-1}$ ) was less than half the $16.2 \pm 1.3 \mathrm{~mm} \mathrm{yr}^{-1}$ recorded under the highest planting density $\left(6.96 \mathrm{~m}^{-2}\right)$. Greater plantation densities also help prevent erosion of deposited sediments by slowing water velocities, and perhaps by promoting greater fine root production to facilitate sediment retention (Krauss et 
1 al., 2003; Lovelock et al., 2007). Friess et al. (2012) suggest that reduced water speeds and fast

2 early root growth (which ensures rapid stabilisation) may be key elements in determining

3 successful colonisation of mangroves in new sites. They discuss the importance of natural

4 variations in these variables, in particular the existence of unusually calm hydrodynamic periods

5 and of fast root growth in pioneer species. Our results suggest that restoration efforts may benefit

6 from deliberate manipulation of these variables by using high densities, slowing water speeds and

7 encouraging sedimentation, which in turn can stimulate root production.

The sediment size classification was medium sand for the site with total sand ranging from

979.75 to $83.83 \%$. Silt provided a smaller fraction of the sediment here than recorded in some comparable studies, such as the 48 to $76 \%$ in the Zhangjiang mangrove estuary of China (Xue et al. 2009), but was similar to the $17 \%$ silt-size fraction reported from Niger Delta sediments

12 (Davies and Abowei, 2009). Sediments with weak texture (dominated by sand) are eroded more

13 easily compared with sediments dominated by clay, which are more resistant to coastal erosion

14 (Yang et al. 2008). Sediments with finer textures also usually have higher nutrient concentrations,

15 partly because of their greater ability to bind nutrients onto particle surfaces and within interstitial

16 spaces. The Palakuda planted plots had only 0.18 to $0.32 \%$ clay in their sediments. In addition to

17 influencing sediment accretion (Kumara et al., 2010), the grain-size distributions of tidal wetland

18 sediments impact the nutrient, OM and water contents of sediments (Lovelock et al., 2007), and

19 determine local biogeochemistry (Dylan and Dahlgren, 2005; Zhou et al., 2007).

20

\section{Impacts of Seedling Density on Roots and Belowground Biomass}

There were significantly higher amounts of fine roots in all planted plots compared to

23 medium and coarse roots. Fine roots are more efficient in absorbing nutrients than coarser roots 
1 as they dramatically increase the surface area for absorption. In the highest seedling density,

2 nutrient demands from the soil should be higher, and therefore, the seedlings in that density need a

3 special strategy to accelerate the rates of nutrient absorption. Regardless of the significant

4 increase in fine roots, none of the tree densities showed significant differences $(p<0.05)$ for

5 medium or coarse roots because these roots may have more of a structural/support role. This

6 finding has also been reported in other studies on mangroves in Micronesia (Cormier et al., 2015)

7 and the Everglades in Florida, USA (Castaneda-Moya et al., 2011).

8 The general trend of reduction of fine root density with depth, except at the 5-10cm depth,

9 shown by all the seedling plantation densities (Figure 4b) also indicated the importance of the

10 upper soil layers in nutrient absorption. The frequent wave and tidal activities are likely to disturb

11 the nutrient absorption in the upper most $0-5 \mathrm{~cm}$ layer and this could be the reason for fewer fine

12 roots at the surface, compared to the underneath $5-10 \mathrm{~cm}$ region which is more stable from

13 disturbances.

The belowground dry weight did not increase proportionally with the increasing seedling

15 density, which was the case with the aboveground biomass production at this site (Kumara et al.,

16 2010). The reason for this is not obvious and uneven growth of roots in the intermediate seedling

17 plantation densities (3.26, 1.93 and $0.95 \mathrm{~m}^{-2}$ ) or low sample size could be the cause; however,

18 further research is needed to understand the actual reasons for this disproportionate growth.

19 Reported mangrove belowground biomass ranges between 0.45 to 30.62 kg dry matter $\mathrm{m}^{-2}$

20 (Komiyama et al., 2008; Tamooh et al., 2008; Cormier et al., 2015); the belowground biomass in

21 this study, even in the highest seedling density $\left(0.11 \pm 6.98 \mathrm{~kg}\right.$ dry matter $\left.\mathrm{m}^{-2}\right)$, did not reach even

22 the lowest limit of this range (probably because of the young age of the mangroves in the study), 
1 suggesting that the rhizosphere was not saturated with roots and that competitive processes were

2 not limiting root growth even at high density.

3

4 Impacts of Seedling Density on Biogeochemical Variables

The surface sediment values of $\mathrm{C}$ and $\mathrm{N}$ recorded in this study were low overall and

6 showed significant differences among treatments. The enhanced sediment $\mathrm{C}$ and $\mathrm{N}$ values

7 recorded in the highest density treatment were probably caused by greater accretion rates at higher

8 planting densities. A global review by Kristensen (2008) reported average sediment C values of

93.6 to $12 \%$ in mangroves. At 0.54 to $0.68 \%$, the current site has unusually low values of C

10 (although sites with values down to 0.1\% have been reported, e.g. Marchand et al., 2003).

11 Increasing age of the trees and limitation of tidal exchanges increase the sediment C (Kristensen,

12 2008; Perry and Berkeley, 2009; Osland et al., 2012), and thus the comparatively low sediment C

13 in Palakuda planted treatments is probably due to the immaturity of the trees and regular tidal

14 exchange.

15 Seedling growth and survival was better at high than low densities, suggesting a

16 facilitative effect between trees (Kumara et al., 2010). This is likely to have resulted from higher

$17 \mathrm{~N}$ supply from the accreting sediments at higher densities. An enhanced supply of N brought

18 about by increased sediment accretion is likely to have compensated for the potential competition

19 for $\mathrm{N}$ under increased seedling densities. Similar positive effects of N supply linked to

20 sedimentation have been recorded elsewhere, although the mechanisms that promote growth may

21 involve stimulation by sedimentation itself as well as through associated nutrient input (Lovelock

22 et al., 2007). 
Salinity can lead to a deficiency of nutrients such as S (Diop et al., 2002). S can also be used as a marker for anoxia. The lack of any differences in S between treatments suggests no differences in oxygen availability or limitation by S. Frequent tidal exchanges at the site and the high rates of sediment accretion might have resulted in this supply. Sediment $\mathrm{pH}$ ranged from 7.6-7.8 among the densities (Table 2) with no significant differences. Most mangrove sediments are acidic because of anaerobic decomposition of organic matter (OM) (Alongi, 2009; p90); this relatively high $\mathrm{pH}$ reflects the low OC content found.

(1)

\section{Isotopic Analysis Reveal Seagrass as a Sediment Carbon Source}

Although the accretion rates varied among the seedling densities, the accreted materials had the same texture and the isotope results suggest they contained the same source $\mathrm{C}$ implying that the sources (rather than amounts) of $\mathrm{C}$ and texture in accreting sediments are independent of the rate of accretion.

Carbon derived from mangrove litter and exudates (Prasad and Ramanadan, 2009) and fine roots typically has $\delta^{13} \mathrm{C}$ values of around -29.75 to -27.64 . Therefore, sediments with values close to these are likely to be dominated by mangrove C inputs, whilst less depleted signatures such as $\delta^{13} \mathrm{C}=-22.4$ imply higher marine influence (Bouillon et al., 2007). The $\mathrm{C}$ isotope values here suggest that marine sources dominated the C pool in the experimental plots.

Mangrove sediments undergo various nitrogenous processes such as mineralization, nitrification, volatization, denitrification and isotope fractionation and produce a wide range of $\delta^{15} \mathrm{~N}$ signatures (typically 0 to $~ 13$ ) (Voss et al., 2005; Hu et al., 2006). For constraining a wide range of $\mathrm{C}$ sources in coastal sediments, the classic $\delta^{15} \mathrm{~N} v s . \delta^{13} \mathrm{C}$ plot is used in this study because 
1 the $\delta^{13} \mathrm{C}$ axis ranges from terrestrial (more negative) to marine (higher) values (Bouillon et al.,

2 2000; Dehairs et al., 2000; Carreira et al., 2002; Barros et al., 2010), while the $\delta^{15} \mathrm{~N}$ axis also

3 represents a sufficient range of $\delta^{15} \mathrm{~N}$ values covering all possible sources. Ideally, the $\delta^{15} \mathrm{~N}$ and

$4 \quad \delta^{13} \mathrm{C}$ limits of the boxes of different sources in Figure 6 would be constructed from isotope

5 readings from the Palakuda experimental site and its terrigenous, mangrove, ocean and seagrass

6 environments; instead the data here are drawn from the literature for other, similar sites. The

7 lagoon bed contains the seagrasses, Cymodocea rotundata and Enhalus acoroides (Johnson and

8 Johnstone, 1995), and we have observed dense beds of these two types of seagrass close to the

9 experimental site. These seagrasses are a possible $\mathrm{C}$ source for the experimental treatments; a

10 similar situation has been reported from Zanzibar mangroves where the sediments of the fringed

11 area recorded ${ }^{13} \mathrm{C}$ values of $-17.6 \pm 0.8 \%$ due to receiving more $\delta^{13} \mathrm{C}$ enriched seagrass material.

12 The seagrass material inputs in that case had enriched the sediment $\delta^{13} \mathrm{C}$ signatures $(-17.6 \%)$

13 close to the range of values from our site (-15.71 to -14.581\%) (Muzuka and Shunula, 2006).

14 A C/N ratio of between 7.85-9.32 implies a marine organic matter input ( $\mathrm{C} / \mathrm{N}=6$ to 9$)$ to

15 this site (Jennerjahn and Ittekkot, 1997). Osland et al. (2012) also found that there was a positive

16 developmental trajectory that indicates a closely associated and fast plant-soil change where the

17 development of mangrove forest occurs simultaneously with upper sediment layer peat

18 development, $\mathrm{N}$ and $\mathrm{C}$ accumulation and changes in bulk density. The location and configuration

19 of mangrove forests determine whether the sediment OC is of mangrove, estuarine or marine

20 origin. The mangrove litter may not be a major component of sediment $\mathrm{C}$ in flow-through

21 ecosystems, whereas closed systems largely accumulate local mangrove production into the

22 underlying sediments (Bouillon et al., 2003). The current experimental site is a flow-through

23 system as water frequently sweeps the entire lagoon bed, and therefore, most of the leaf litter from 
1 these relatively small planted plots is probably exported to the lagoon water / marine environment

2 with the outgoing tides.

\section{Conclusions}

The density of mangroves affected the granulometry and chemistry of accreting sediment

5 and the belowground biomass of the trees. The highest seedling density had the highest

6 belowground biomass and the greatest numbers of fine roots for efficient absorption of nutrients,

7 with the highest number of total roots present at soil depths of 5-10 cm. Higher seedling densities

8 had higher levels of sediment accretion and associated nutrient content. The $\mathrm{C} / \mathrm{N}$ ratio for

9 sediments in planted treatments differed significantly from the unplanted control, reflecting the

10 enhanced $\mathrm{N}$ found in planted plots. The $\delta^{15} \mathrm{~N}$ range of the treatments could represent material of

11 both seagrass and mangrove origin, while the $\delta^{13} \mathrm{C}$ range of the treatments is indicative of

12 enriched $\mathrm{C}$ of seagrass origin. Sediments from all the treatments (including unplanted controls)

13 ranged from -16.41 to -14.58 for $\delta^{13} \mathrm{C}$ and 2.80 to 2.40 for $\delta^{15} \mathrm{~N}$ with no significant differences in

14 the $\%$ o $\delta^{13} \mathrm{C}$ and $\delta^{15} \mathrm{~N}$ in sediments among different mangrove densities; taking these isotopic

15 results together suggests that most $\mathrm{C}$ in the plots was derived from allochthonous sources.

16 Sediment \%N and \%C differed significantly among densities, which suggests one potential causal

17 mechanism for the facilitatory effects on growth previously observed: high densities of plants

18 potentially contribute to the accretion of greater amounts of nutrient-rich sediment, which may be

19 particularly important at this site which has low levels of $\mathrm{C}, \mathrm{N}$ and silt in the ambient sediment.

20 The current study involved a single sampling of sediment after 880 days of planting, and hence,

21 the conclusions are mostly applicable for the initial growth of the mangroves only. A more

22 detailed study with samplings at different growth stages of these experimental plots is required to

23 understand the long-term dynamics of the measured sediment parameters. 


\section{Acknowledgements}

The authors thank Earthwatch Institute and Zurich International for funding this project. They also thank Earthwatch Institute for providing volunteers who helped with the planting of mangroves at the site. Any use of trade, firm, or product names is for descriptive purposes only and does not imply endorsement by the U.S. Government.

\section{References}

Alongi, D.M. 2009. The Energetics of Mangrove Forests, Springer Science, Netherlands, p. 216.

Alongi, D.M., Dixon, P. 2000. Mangrove primary production and above-and belowground biomass in Sawi bay, southern Thailand. Phuket Mar. Biol. Center Spec. Publ. 22: 31-38.

Barros, G.V., Martinelli, L.A., Novais, T.M.O., Ometto, J.P.H.B., Zuppi, G.M. 2010. Stable isotopes of bulk organic matter to trace carbon and nitrogen dynamics in an estuarine ecosystem in Babitonga Bay (Santa Catarina, Brazil). Sci. Tot. Environ. 408, 2226-2232.

Bauer, J.E., Druffel, E.R.M., Wolgast, D.M., Griffin, S. 2002. Temporal and regional variability in sources and cycling of DOC and POC in the northwest Atlantic continental shelf and slope. Deep-Sea Res. 49, 4387-4419.

Bournazel, J., Kumara, M. P., Jayatissa, L. P., Viergever, K., Morel, V., \& Huxham, M. 2015. The impacts of shrimp farming on land-use and carbon storage around Puttalam lagoon, Sri Lanka. Ocean Coast. Manage. 113, 18-28.

Bouillon, S., Chandra, M.P., Sreenivas, N., Dehairs, F. 2000. Sources of suspended organic matter and selective feeding by zooplankton in an estuarine mangrove ecosystem as traced by stable isotopes.Mar. Ecol. Prog. Series. 208, 79-92.

Bouillon, S., Dahdouh-Guebas, F., Rao, A.V.V.S., Koedam, N., Dehairs, F. 2003. Sources of organic carbon in mangrove sediments: variability and possible ecological implications. Hydrobiologia. 495, 33-39.

Bouillon, S., Koedam, N., Dehairs, F. 2002. Primary producers sustaining macro-invertebrate communities in intertidal mangrove forests. Oecologia. 130, 441-448.

Bouillon, S., Middelburg, J.J., Dehairs, F., Borges, A.V., Abril, G., Flindt, M.R., Ulomi, S., Kristensen, E. 2007. Importance of intertidal sediment processes and porewater exchange on the water column biogeochemistry in a pristine mangrove creek (RasDege, Tanzania). Biogeosciences Discuss. 4, 317-348. 
Cahoon, D.R., Lynch, J.C. 1997. Vertical accretion and shallow subsidence in a mangrove forest of south-western Florida, USA. Mangroves and Salt Marshes 1, 173-186.

Carreira, R.S., Wagener, A.R., Fileman, T., Readman, J., Macko, S.A., Veiga, A. 2002. Changes in sedimentary organic carbon pool of a fertilized tropical estuary, Guanabara Bay, Brazil: an elemental, isotopic and molecular marker approach. Mar. Chem. 79, 207-27.

Comley, B.W.T., McGuinness, K.A, 2005. Above and below-ground biomass, and allometry four common northern Australian mangroves. Australian J. Botany. 53: 431-436.

Cormier, N., Twilley, R.R., Ewel, K.C., Krauss, K.W. 2015. Fine root productivity varies along nitrogen and phosphorus gradients in high-rainfall mangrove forests of Micronesia. Hydrobiol. 750, 69-87.

Castaneda-Moya, E.R, Twilley, R.R., Rivera-Monroy, V.H., Marx, B.D., Coronado-Molina, C., Ewe, S.M.L. 2011. Patterns of root dynamics in mangrove forests along environmental gradients in the Florida Coastal Everglades, USA. Ecosystems. 14, 1178-1195.

Davies, O.A., Abowei, J.F.N. 2009. Sediment quality of lower reaches of Okpoka Creek, Niger Delta, Nigeria. European J. Scientific Res. 26: 437-442.

Dehairs, F., Rao, R.G., Chandra, M. P, Raman, V., Marguillier, S., Hellings, L. 2000. Tracing mangrove carbon in suspended matter and aquatic fauna of the Gautami-Godavari Delta, Bay of Bengal (India). Hydrobiologia. 431, 225-41.

Diop, E.S., Gordon, C., Semesi., A.K., Soumare, A., Diallo, N., Guisse, A., Diouf, M., Ayivor, J.S. 2002. Mangroves in Africa. Pp. 63- 121, In: Magrove Ecosystems: Function and Management. Luiz Drude de Lacerda (ed). Springer-Verlag Berlin, pp. 287.

Duke, N.C. 2006. Australia’s mangroves.University of Queensland, Brisbane, QLD, Australia.

Dylan, S.A., Dahlgren, R.A. 2005. Sediment and nutrient dynamics following a low-head dam removal at Murphy Creek, California. Limnol. Oceanogr. 50, 1752-1762.

Fontugne, M.R., Duplessy, J.C. 1981. Organic carbon isotopic fractionation by marine plankton in the temperature range -1 to 31C. Oceanologica Acta. 4, 85-90.

Friess, D. A., Krauss, K. W., Horstman, E. M., Balke, T., Bouma, T. J., Galli, D., \& Webb, E. L. 2012. Are all intertidal wetlands naturally created equal? Bottlenecks, thresholds and knowledge gaps to mangrove and saltmarsh ecosystems. Biological Reviews, 87, 346-366. Fry, B. 2006. Stable isotope ecology. Springer Science, New York, USA 390pp

Fry, B., Sherr, E.B. 1984. $\delta^{13} \mathrm{C}$ measurements as indicators of carbon flow in marine and freshwater ecosystems. Contributions in Mar. Sci. 27, 13-47. 
Furukawa, K., Wolanski, E., Mueller, H. 1997. Currents and sediment transport in mangrove forests. Estuar. Coast. Shelf. Sci. 44, 301-310.

Furukawa, K., Wolanski, E. 1996. "Sedimentation in mangrove forests". Mangroves and Salt Marshes 1, 3-10.

Gedan, K. B., Silliman, B. R. 2009. Using facilitation theory to enhance mangrove restoration. Ambio, 38, 109.

Gilman, E., Ellison, J., Jungblat ,V., VanLavieren, H., Wilson, L., Areki, F., Brighouse, G., Bungitak, J., Dus, E., Henry, M, Sauni I. Jr, Kilman, M., Matthews, E., Teariki-Ruatu, N., Tukia, S., Yuknavag, K. 2006. Adapting to Pacific Island mangrove responses to sea level rise and other climate change effects. Climate Res. 32, 161-176.

Gilman, E.L., Ellison, J., Duke, N.C., Field, C. 2008. Threats to mangroves from climate change and adaptation options. Aquat. Bot. 89, 237- 250.

Gilman, E., Ellison, J., Coleman, R. 2007. Assessment of mangrove response to projected relative sea-level rise and recent historical reconstruction of shoreline position. Environ. Monitor. Assess. 124, 112-134.

Hemminga, M.A. \& Mateo, M.A. 1996. Stable carbon isotopes in sea-grasses: variability in ratios and use in ecological studies. Marine Ecology Progress Series 140: 285-298.

Hu, J., Peng, P., Jia, G., Mai, B., Zhang, G. 2006. Distribution and sources of organic carbon, nitrogen and their isotopes in sediments of the subtropical Pearl River estuary and adjacent shelf, Southern China. Mar. Chem. 98, 274-285.

Huxham, M., Kumara, M.P., Jayatissa, L.P., Krauss, K.W., Kairo, J., Langat, J., Mencuccini, M., Skov, M., Kirui, B. 2010. Intra and inter-specific facilitation in mangroves may increase resilience to climate change threats. J. Philosoph. Trans. Royal Soc. B. 365, 2127-2135.

IUCN. 2009. Sri Lanka National Strategy and Action Plan. Mangroves for the Future Programme, IUCN Sri Lanka Country Office, Colombo. xxxii + 219pp available at https://www.iucn.org/sites/dev/files/import/downloads/nsap_1.pdf

Jahnke, R.A. 2005. Transport processes and organic matter cycling in coastal sediments. In: Robinson, A.R., Brink, K.H. (Eds.), The Sea: The Global Coastal Ocean Multiscale Interdisciplinary Processes. Harvard University Press, Massachusetts, pp. 163-192.

Jennerjahn, T.C., Ittekkot, V. 1997. Organic matter in sediments in the mangrove areas and adjacent continental margins of Brazil. I. Amino acids and hexosamines. Oceanologica Acta. 20, 359-369.

Jayatissa, L.P., Dahdouh-Guebas, F., Koedam, N. 2002. A review of the floral composition and distribution of mangroves in Sri Lanka. Botanical J. Linnean Soc. 138, 29-43. 
Johnson, P., Johnstone, R. 1995. Productivity and nutrient dynamics of tropical seagrass communities in Puttalam lagoon, Sri Lanka. Ambio. 24, 411-417.

Kathiresan, K., Bingham, B.L. 2001. Biology of mangroves and mangrove ecosystems. Advances in Mar. Biol. 40, 81-251.

Komiyama, A., Havanond, S., Srisawatt, W., Mochida, Y., Fujimoto, K., Ohnishi, T., Ishihara, S., Miyagi, T. 2000. Top/root biomass ratio of a secondary mangrove (Ceriops tagal (Perr.) C.B. Rob.) forest. Forest Ecol. Manage. 139, 127-134.

Krauss, K.W., Allen, J.A., Cahoon, D.R. 2003. Differential rates of vertical accretion and elevation change among aerial root types in Micronesian mangrove forests. Estuar. Coast. Shelf. Sci. 56, 251-259.

Krauss, K.W., McKee, K.L., Lovelock, C.E., Cahoon, D.R., Saintilan, N., Reef, R., Chen, L. 2014. How mangrove forests adjust to rising sea level. New Phytol. 202, 19-34.

Kristensen, E. 2008. Mangrove crabs as ecosystem engineers; with emphasis on sediment processes. J. Sea Res. 59, 30-43.

Kumara, M.P., Jayatissa, L.P., Krauss, K.W., Phillips, D.H., Huxham, M. 2010. High mangrove density enhances surface accretion, surface elevation change, and tree survival in coastal areas susceptible to sea-level rise. Oecologia. 164, 545-553.

Lovelock, C.E., Feller, L.C., Ellis, J., Schwarz, A.M., Hancock, N., Nichols, P., Sorrell, B. 2007. Mangrove growth in New Zealand estuaries: the role of nutrient enrichment at sites with contrasting rates of sedimentation. Oecologia. 153, 633-641.

Marchand, C., Lallier-Verge E., Baltzer, F. 2003. The composition of sedimentary organic matter in relation to the dynamic features of a mangrove-fringed coast in French Guiana. Estuar. Coast. Shelf. Sci. 56, 119-130.

McKee, K.L., Cahoon, D.R., Feller, I.C. 2007. Caribbean mangroves adjust to rising sea level through biotic controls on change in soil elevation. Global Ecol. Biogeogr. 16, 545-556.

McLeod E., Salm, R. 2006. Managing mangroves for resilience to climate change. IUCN, Gland, Switzerland.

McMillan, C. 1980. I3C/l2C ratios in seagrasses. Aquatic Botany 9: 237-249.

Melville, A.J., Connolly, R.M. 2003. Spatial analysis of stable isotope data to determine primary sources of nutrition. Oecologia 136, 499-507.

Muzuka, A.N.N., Shunula, J.P. 2006. Stable isotope compositions of organic carbon and nitrogen of two mangrove stands along the Tanzanian coastal zone. Estuar. Coast. Shelf Sci. 66, 447-458. 
Odum, W.E., Heald, E.J. 1975. The detritus-based food web of an estuarine mangrove community.In: Cronin, L.E. (ed) Estuarine Research. Academic Press Inc., New York. pp. 268286.

Ong, J.E., Gong, W.K., Wong, C.H. 2004. Allometry and partitioning of mangrove, Rhizophora apiculata. Forest Ecol. Manage. 188, 395-408.

Osland, M.J., Spivak, A.C., Nestlerode, J.A., Lessmann, J.M., Almario, A.E., Heitmuller, P.T., Russell,M.J., Krauss.K.W., Alvarez, F., Dantin. D.D., Harvey, J.E., From, A.S., Cormier, N., Stagg,C.L. 2012. Ecosystem Development After Mangrove Wetland Creation: Plant-Soil Change Across a 20-Year Chronosequence. Ecosystems. 15, 848-866.

Otero, E., Culp, R., Noakes, J.E., Hodson, R.E. 2000. Allocation of particulate organic carbon from different sources in two contrasting estuaries of south-eastern U.S.A. Limnol. Oceanogr. 45, 1753-1763.

Peech, M. 1965. Hydrogen-Ion Activity. In: Methods of Soil Analysis. Part 2. Chemical and Microbiological Properties, Agronomy monograph 9.2. A.G. Norman (ed.) p 914-926.

Perry, C.T., Berkeley, A. 2009. Intertidal substrate modification as a result of mangrove planting: Impacts of introduced mangrove species on sediment microfacies characteristics. Estuar. Coast. Shelf. Sci. 81, 225-237.

Pinnegar, J.K., Polunin, N.V.C. 1999. Differential fractionation of d13C and d15N among fish tissues: implications for the study of trophic interactions. Functional Ecology. 13, 225-231.

Prasad, M.B.K., Ramanathan, A.L. 2009. Organic matter characterization in a tropical estuarinemangrove ecosystem of India: Preliminary assessment by using stable isotopes and lignin phenols. Estuar. Coast. Shelf. Sci. 84, 617-624.

Quartel, S., Kroon, A., Augustinus, P.G.E.F., Van Santen, P., Tri, N.H. 2007. Wave attenuation in coastal mangroves in the Red River Delta, Vietnam. J. Asian Earth Sci. 29, 576-584.

Ramanathan, A.L., Rajkumar, K., Majumdar, J., Singh, G., Behera, P.N., Santra, S.C., Chidambaram, S. 2009. Textural characteristics of the surface sediments of a tropical mangrove Sundarban ecosystem India. Indian J. Mar. Sci. 37, 397-403.

Reef, R., Feller, I.C., Lovelock, C.E. 2010. Nutrition of mangroves. Tree Physiol. 30, 1148-1160.

Saintilan, N. 1997a. Above- and below-ground biomasses of two patterns of biomass and ANPP in a mangrove ecosystem species of mangrove on the Hawkesbury River estuary, New South Wales. Marine Freshwater Res. 48, 147-152.

Saintilan, N. 1997b. Above- and below-ground biomass of mangroves in a subtropical estuary. Marine Freshwater Res. 48, 601-604. 
Schweizer, M., Fear, J., Cadisch, G. 1999. Isotopic $\left({ }^{13} \mathrm{C}\right)$ Fractionation During Plant Residue Decomposition and its Implications for Soil Organic Matter Studies. Rapid Commun. Mass Spectrom.13, 1284-1290.

Smith, B., Epstein, S. 1971. Two categories of ${ }^{13} \mathrm{C} /{ }^{12} \mathrm{C}$ for higher plants. Plant Physiol. 47, 380384.

Tamooh, F., Huxham, M., Karachi, M., Mencuccini, M., Kairo, J.G., Kirui, B. 2008. Belowground root yield and distribution in natural and replanted mangrove forests at Gazi bay, Kenya. Forest Ecol. Manage. 256, 1290-1297.

Thornton, S.F., McManus, J. 1994. Application of organic carbon and nitrogen stable isotope and $\mathrm{C} / \mathrm{N}$ ratios as source indicators of organic matter provenance in estuarine systems: Evidence from the Tay estuary, Scotland. Estuar. Coast. Shelf. Sci. 38, 219-233.

Vizzini, S., Mazzola, A. 2003. Seasonal variations in the stable carbon and nitrogen isotope ratios $(13 \mathrm{C} / 12 \mathrm{C}$ and $15 \mathrm{~N} / 14 \mathrm{~N})$ of primary producers and consumers in a western Mediterranean coastal lagoon. Marine Biology 142, 1009-1018.

Voss, M., Liskowa, I., Pastuszak, M., Rüß, D., Schultec, U., Dippnera, J.W. 2005. Riverine discharge into a coastal bay: a stable isotope study in the Gulf of Gdańsk, Baltic Sea. J. Mar. Syst. 57, 127-45.

Wolanski, E., Mazda, Y. \& Ridd, P. 1992. Mangrove hydrodynamics. In: Robertson A. I. \& Alongi, D. M. (eds.), Tropical Mangrove Ecosystems, American Geophysical Union, Washington D.C. pp. 43-62.

Xue, B., Yan, C., Lu, H., Bai, Y. 2009. Mangrove-Derived Organic Carbon in Sediment from Zhangjiang Estuary (China) Mangrove Wetland. J. Coast. Res. 25, 949-956.

Yang, S.L., Li, H., Ysebaert, T., Bouma, T.J., Zhang, W.X., Wang, Y.Y., Li, P., Li, M., Ding, P.X. 2008. Spatial and temporal variations in sediment grain size in tidal wetlands, Yangtze Delta: On the role of physical and biotic controls. Estuar. Coast. Shelf. Sci. 77, 657-671.

Yu, F., Zong, Y., Jeremy, M.L., Huang, G., Melanie, J.L., Christopher, .K, Angela, L.L., Wyss, W.S.Y. 2010. Bulk organic $\delta^{13} \mathrm{C}$ and $\mathrm{C} / \mathrm{N}$ as indicators for sediment sources in the Pearl River delta and estuary, southern China. Estuar. Coast. Shelf. Sci. 87, 618-630.

Zhou, J.L., Wu, Y., Kang, Q.S., Zhang, J., 2007. Spatial variations of carbon, nitrogen, phosphorous and sulphur in salt marsh sediments of the Changjiang Estuary, China. Estuar. Coast. Shelf. Sci. 71, 47-59. 


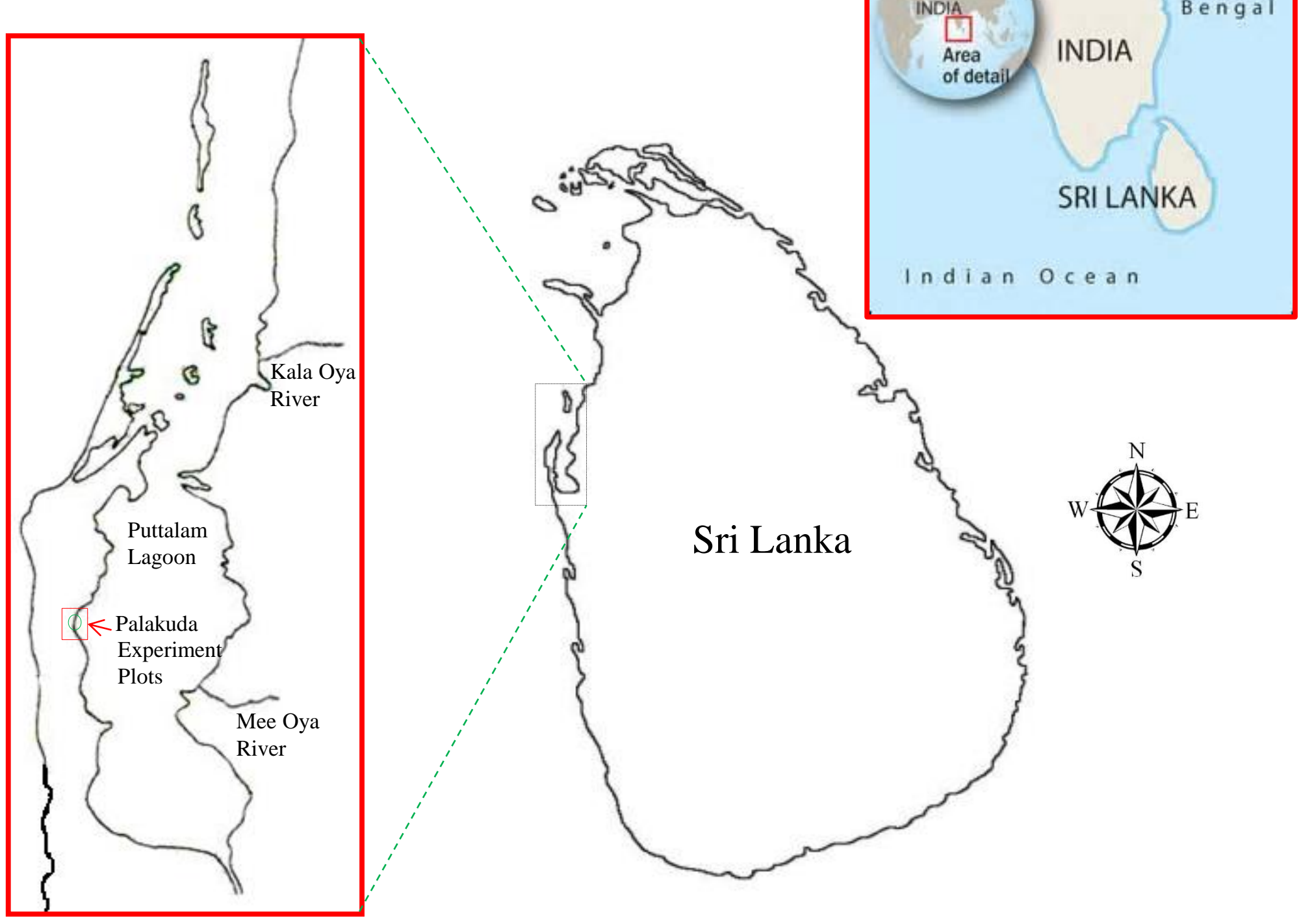

Figure 1. Location of Palakuda within Puttalam Lagoon in Sri Lanka where the experimental plots were established. 


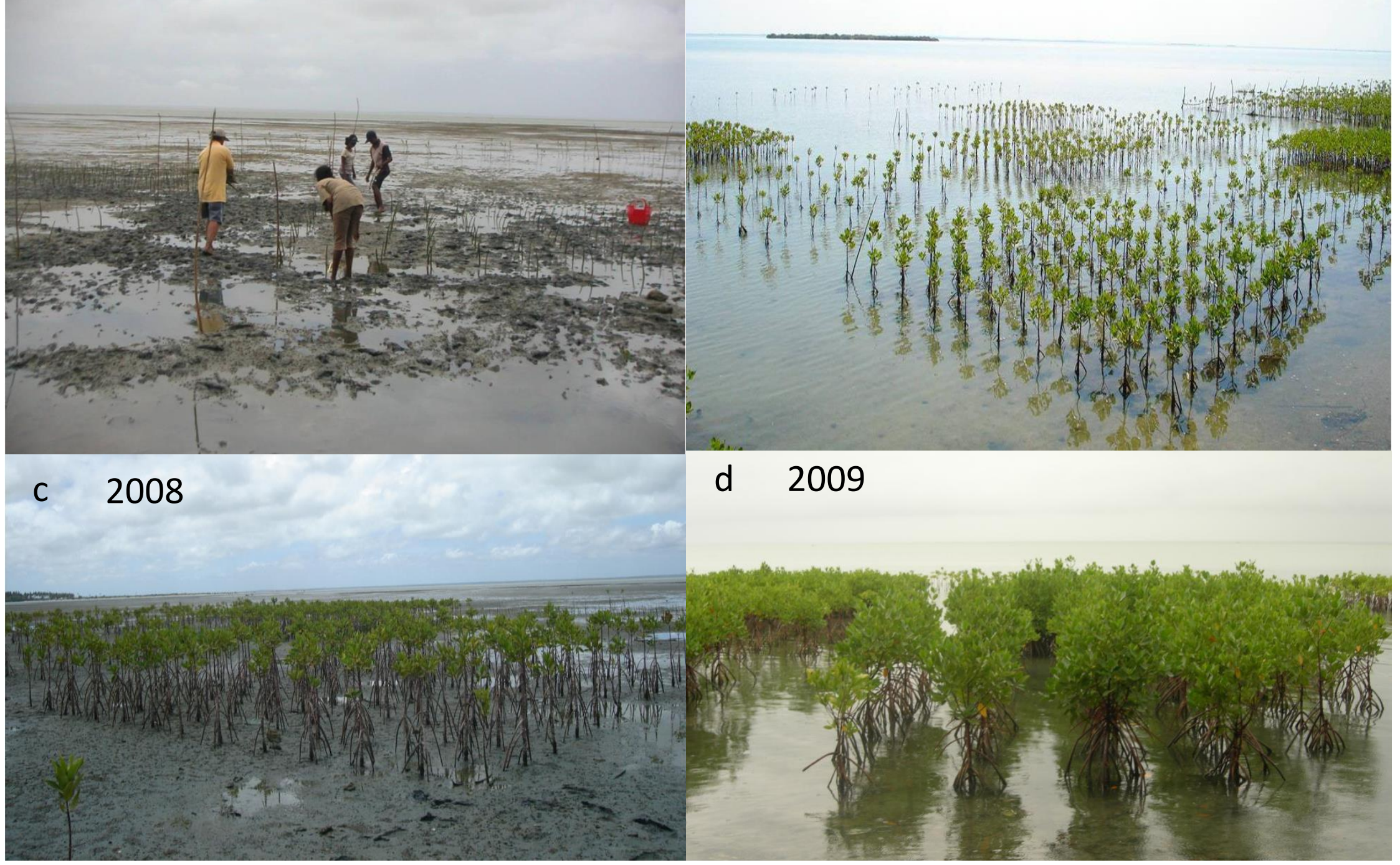

Figure 2. Palakuda experimental site, Puttalam Lagoon, Sri Lanka. A) Planting of R. mucronata seedlings in 2006, and tree growth in plots in b) 2007, c) 2008, and d) 2009. 


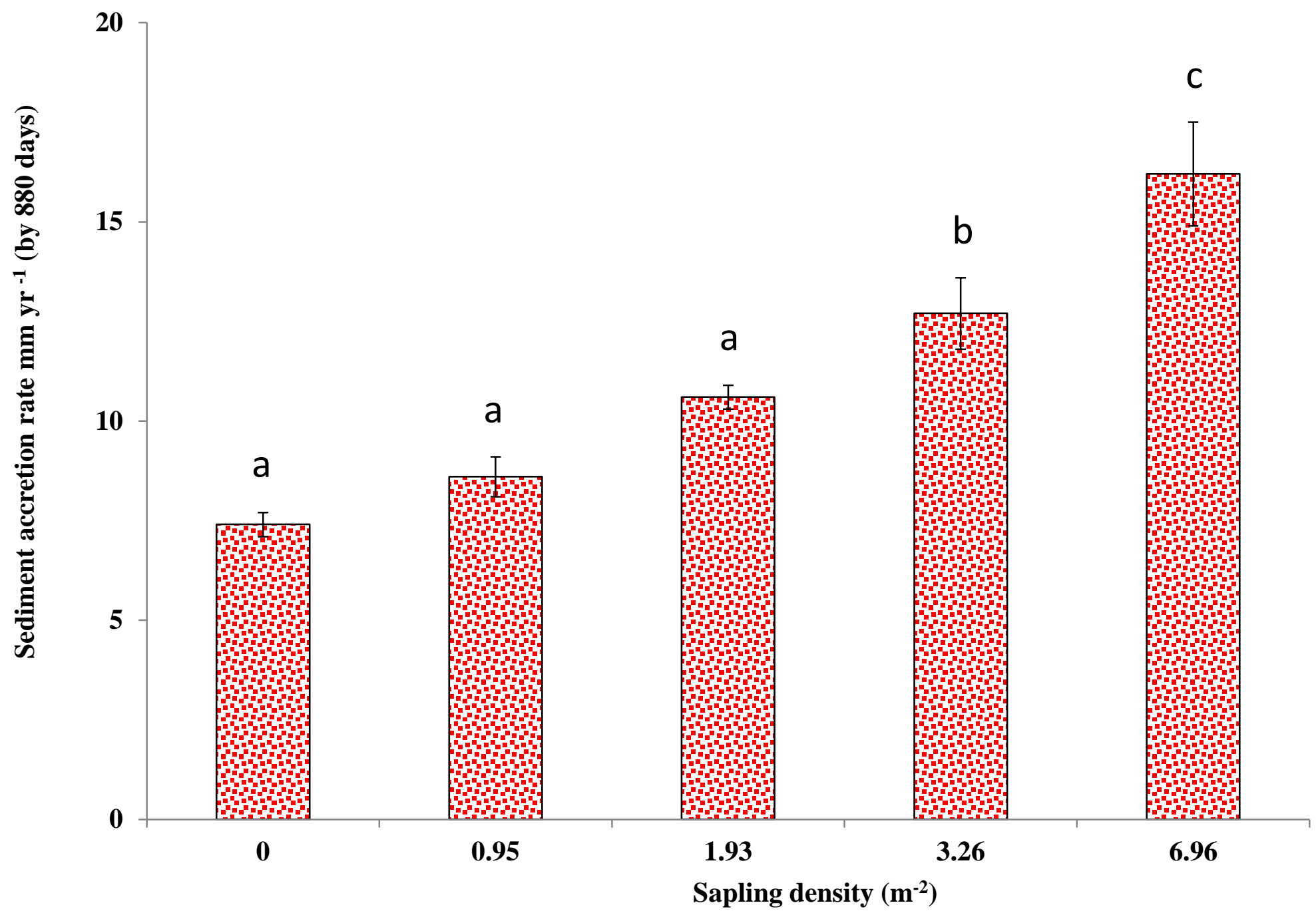

Figure 3. Mean ( \pm SE) accretion rates over 880 days. Letters show statistically distinct means. 


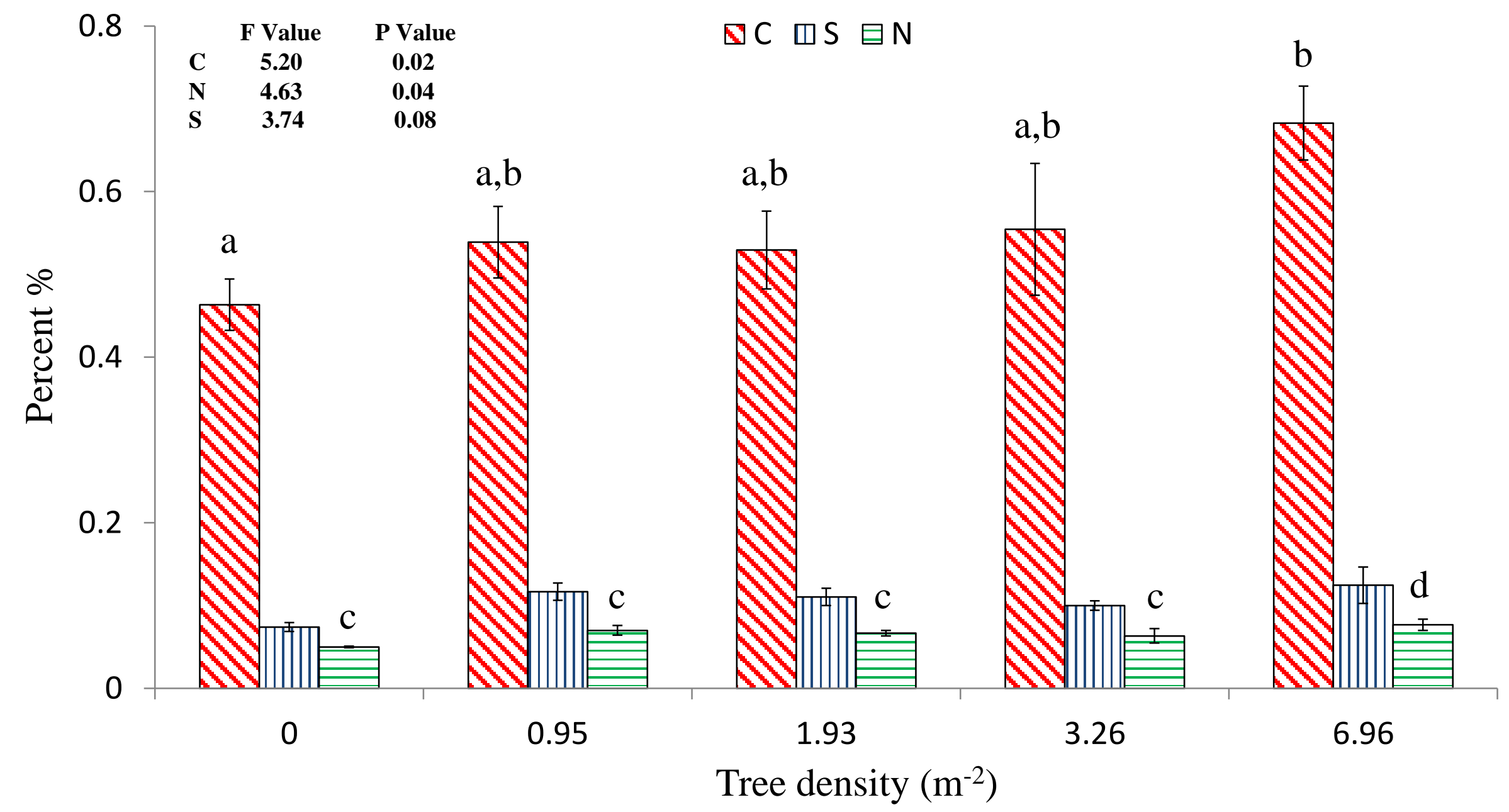

Figure 5. Percent (means $\pm \mathrm{SE}$ ) carbon, sulphur, and nitrogen for the different tree densities in the study. Letters show statistically distinct means. The $p$ and $f$ values obtained from Two-way ANOVA test. 


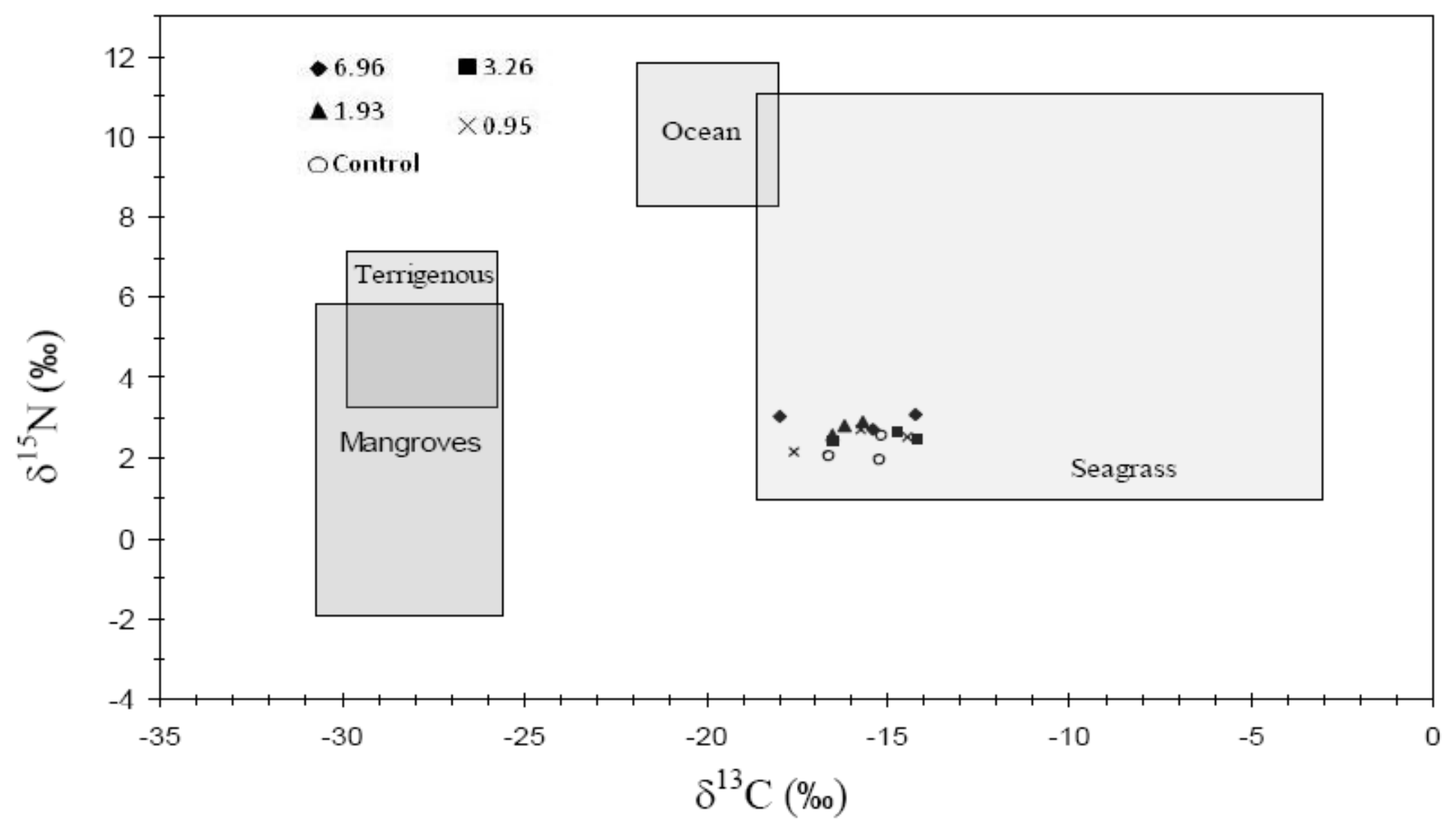

Figure 6. Position of different $R$. Mucronata density treatments with $\delta^{15} \mathrm{~N}$ vs $\delta^{13} \mathrm{C}$ plot of potential sources. Different symbols indicated different treatments. Sources used for producing the limits of the shaded boxes: McMillan, 1980; Fontugne and Duplessy, 1981; Fry and Sherr, 1984; Meyers, 1984; Macia, 1995; Hemminga and Mateo, 1996; Jennerjahn and Ittekkot, 1997; Marguillier et al., 1998; Anderson and Fourqurean, 2003; Lepoint et al., 2003; Melville and Connolly, 2003; Vizzini and Mazzola, 2003; Bouillon et al., 2004; Muzuka and Shunula, 2006; Prasad and Ramanadan, 2009; Barros et al., 2010. 